\title{
Economic and IT determinants of innovative projects in the textiles, wearing apparel, leather and related products industry
}

CEZAR-PETRE SIMION

DOI: $10.35530 / 1 T .069 .04 .1478$

ADRIANA ALEXANDRU

SEBASTIAN ION CEPTUREANU EDUARD GABRIEL CEPTUREANU

\section{REZUMAT - ABSTRACT}

Principalii factori economici și IT care influenţează proiectele inovative din domeniul textilelor, articolelor de îmbrăcăminte, pielăriei și produselor înrudite

În această lucrare au fost indentificaţi şi analizaţi principalii factori care influenţează proiectele inovative din domeniul textilelor, articolelor de îmbrăcăminte, pielăriei şi produselor înrudite. Au fost luaţi în considerare unsprezece factori potenţiali ce pot influenţa proiectele inovative, iar în urma analizei de corelaţie au fost identificaţi cei doi factori care au influenţă esenţială asupra proiectelor inovative din domeniu: indicele volumului producţiei din Uniunea Europeană pentru codurile NACE 13-15 şi exporturile din domeniul textilelor, articolelor de îmbrăcăminte, pielăriei şi produselor înrudite. Cercetarea realizată a arătat că amploarea proiectelor inovative din domeniul textilelor, articolelor de îmbrăcăminte, pielăriei şi produselor înrudite depinde de producţia din Uniunea Europeană şi de cererea pe plan mondial.

Cuvinte-cheie: proiecte, inovativ, textile, IT, articole de îmbrăcăminte

Economic and IT determinants of innovative projects in the textiles, wearing apparel, leather and related products industry

In this paper the main factors that influence the innovative projects in the field of textiles, wearing apparel, leather and related products were identified and analyzed. Eleven potential factors influencing innovative projects have been considered and the correlation analysis has identified the two factors that have a major influence on innovative projects in the field: volume index of production in European Union for NACE codes 13-15 and exports value for textiles, wearing apparel, leather and related products. The research has shown that the scale of innovative projects in textiles, clothing, leather and related products depends on European Union production and on global demand.

Keywords: projects, innovative, textiles, IT, wearing apparel

\section{INTRODUCTION}

A very long time textiles, wearing apparel, leather and related products industry from Romania has benefited from the competitive advantage of low wages, which has led to the lohn system for the major producers in the field in the European Union. After Romania's accession to the European Union, Romanian companies benefited from the advantages of the single market, but began to lose the competitive advantage of reduced labor as the average salary in Romania started to rise and the skilled workers emigrated to countries within the European Union that offered salaries more attractive and other career prospects and living standards. Popescu (2013) revealed "the lack of qualified personnel in the labor market in Romania's clothing industry, especially among directly productive workers" [9].

In the current period, a number of additional threats to the sustainability of the business sector have emerged at the level of the Romanian textiles, wearing apparel, leather and related products industry: the increase of the national minimum wage, the impossibility to use part-time coupons due to the same contributions as for full-time employment contracts, lack of highly skilled workforce, suppliers' tendency to export raw materials directly due to more attractive prices in other markets. All of these additional threats directly lead to the loss of competitive advantage at the sectoral level and the tendency of big manufacturers to re-orient lohn production to other countries where wage costs are lower.

The Romanian textiles, wearing apparel, leather and related products industry has entered a period of strategic reorientation from looking for competitive advantage based on reduced costs to competitive advantage based on differentiation. In this context, a number of Romanian companies have emerged that have the tendency to innovate permanently and in the same rhythm as the big producers in the field. New entrants have very aggressive marketing policies and create their own brands that they are trying to impose on the local market in front of the European Union brand name competition, with unequivocally uneven resources.

The capacity to innovate of the Romanian textile companies is still low compared to the EU average but the Romanian industry tends to synchronize with the strategic approaches envisaged for the European Union. Thus, in the study "Textiles and Clothing in the EU" of the European Commission, Romania is mentioned in the "low-cost areas" category with a major risk of relocation of production in the 2020 horizon. The main factors of the change mentioned in this study are: global knowledge base (including new applications of textiles such as "smart" textiles in medicine or construction) and environmental costs. 
Also, the studies made by other authors start from the hypothesis that "innovation represents the main implication for developed countries to expand the industrial base in textiles and clothing (Şerbănel, 2014) [10].

That is why it is very useful to study the factors that influence the scale of the innovative projects of the Romanian textile industry organizations in order to observe the elements that have direct consequences on the innovation in the field. In this article we study the factors influencing the innovation projects in the field of products as well as in the managerial or marketing fields.

\section{LITERATURE REVIEW}

The study of the role and effects of innovation and innovative projects on the textile industry included several approaches. A first approach is to analyze the content of innovative projects and their effect on the textile industry at global, regional or local level. Kaounides, Yu and Harper (2007) analyzed how innovations in nanotechnologies and their applications in the textile industry influence this industry. The authors believe that "emerging nanoenabled performance improvements and new categories in textiles will increasingly drive R\&D and commercialization" [6]. Lottersberger (2011) analyzed from a different perspective the relationship between research and the design of new products in the textile industry in order to develop "a strategic model and specific tools for starting a Design Driven Innovation process into a textile company, in order to achieve radical meaning innovations" [7].

Some authors believe that in the textile industry in Romania "technological innovation is at an extremely low level due to the incipient links between universities, research centers and companies but also because research and development expenditures at firm level are very low" (Şerbănel, 2014) [10]. Ceptureanu S.I., Ceptureanu E.G. and Visileanu E. (2017) concluded that "Romanian SMEs from clothing industry prefer cost-based approaches" [2].

Zucchella and Siano (2014) focused on the study of innovation as a resource in the expansion of Italian SMEs in the textile industry on foreign markets. These authors concluded that the success of small Italian firms in foreign markets is the source of internationalization and innovation but not the result of their own R \& D activity or taken over from specialized organizations, but rather sources of specialized knowledge from the strong links with pivotal centers of the industry [12].

Gîrneaţă, Giurgiu, Dobrin, Popa, Popescu et al. (2015) following the analysis performance management practices in Romanian textile and clothing companies have determined that in future research "it is necessary to include, among performance indicators, the adaptation to market demands and technological innovation" [3] which shows that performance in the textile industry in Romania can be explained through innovation as well.

A second approach is the work that analyzes the determinants of innovation in the textiles, wearing apparel, leather and related products industry. Macchion et al. (2017) analyzed how environmental protection practices and supply chain collaboration imply better innovation performance and differentiation from competitors in terms of product or process quality [8]. Research conducted on the main Italian companies has shown that there is a positive impact on environmental performance practices in innovation performance. More and more restrictive environmental regulations force companies to innovate and/ or adopt innovations in a way that complies with new practices in the field. Organizations that are unable to adapt by innovation to new practices are eliminated from the market due to the impossibility of meeting a number of minimum standards.

Ceptureanu S.I., Ceptureanu E.G., Simion-Melinte C. and Borisov D. (2016) concluded that "a competitive advantage based on innovation in the clothing industry requires the development of organizational strategies based on knowledge organizational capability" [1]. The results obtained by these authors lead to the conclusion that product or process innovation requires actions centered on organizational knowledge. In the same direction, other authors (Florescu and Ivanov, 2016) noted that globalization can act as a factor of influence on the research and development activity of the textile industry in Romania [4]. The presence of foreign firms requires an effort to adapt their products and services to the local market, which may lead to an increase in the potential demand for R\&D services.

Another new approach to innovation in the textiles, wearing apparel, leather and related products industry starts from the Fourth Industrial Revolution and the 4.0 Production Concept, very much linked to the Internet of Things and ICT sector. Jayatilake and Withanaarachchi (2016) consider in a study on the IT side of applying the concept of Production 4.0 that Sri Lankan wearing apparel industries have already begun to assimilate a series of characteristics of this type of production and that in terms of information and communication technology sector, the internet and the supporting technologies (such as Internet of Things, embedded systems, big data, etc.) serve as the main pillar to assimilate, human factors, production lines, intelligent machines physical objects and processes across apparel industry to form an agile value chain" [5]. In the textile and clothing industry is used the equivalent term Fashion 4.0 based on digital materials and 3D printing.

Based on the analysis of the literature, it can be noticed that although the majority of authors analyze the link between the innovation activity (or, in general, research and development) and the trends in the textile industry, no analysis has yet been made that 
determines the factors influencing the more innovative projects in the Romanian textiles, wearing apparel, leather and related products industry.

\section{RESEARCH METHODOLOGY}

Since there have been no dedicated studies to analyze the factors influencing innovative textile projects in Romania, the current research has had the following objectives:

- Analysis of specialized literature and identification of potential factors of influence on innovative projects in the textile industry in Romania;

- Selection of relevant data for the research performed;

- Analyzing the data and identifying those factors that influence the innovative projects in the textile industry in Romania;

- Reporting the results obtained from other studies in the literature.

The main steps of the research methodology used, as well as their sequence, are shown in the figure 1. of textiles, wearing apparel, leather and related products".

- Trade by commodity and NACE Rev. 2 activity [ext_tec05], - extracted on 8/28/2017, last update 8/22/2017.

- Organisational and marketing innovation in product and process innovative enterprises by NACE Rev. 2 activity and size class: [inn_cis7_mo] [inn_cis8_mo] [inn_cis9_mo].

- Product and process innovation by NACE Rev. 2 activity and size class: [inn_cis7_prod] [inn_cis8_prod] [inn_cis9_prod].

- Total expenditure on R \& D activity in the enterprise sector, by category of expenditure and by NACE Rev. 2 activities - current prices (National Institute of Statistics databases).

- Net investment in national economy activities at division and division level, NACE Rev. 2 (National Institute of Statistics databases).

4. Hypothesis formulation: eight hypotheses were formulated using preliminary data analysis and literature review.

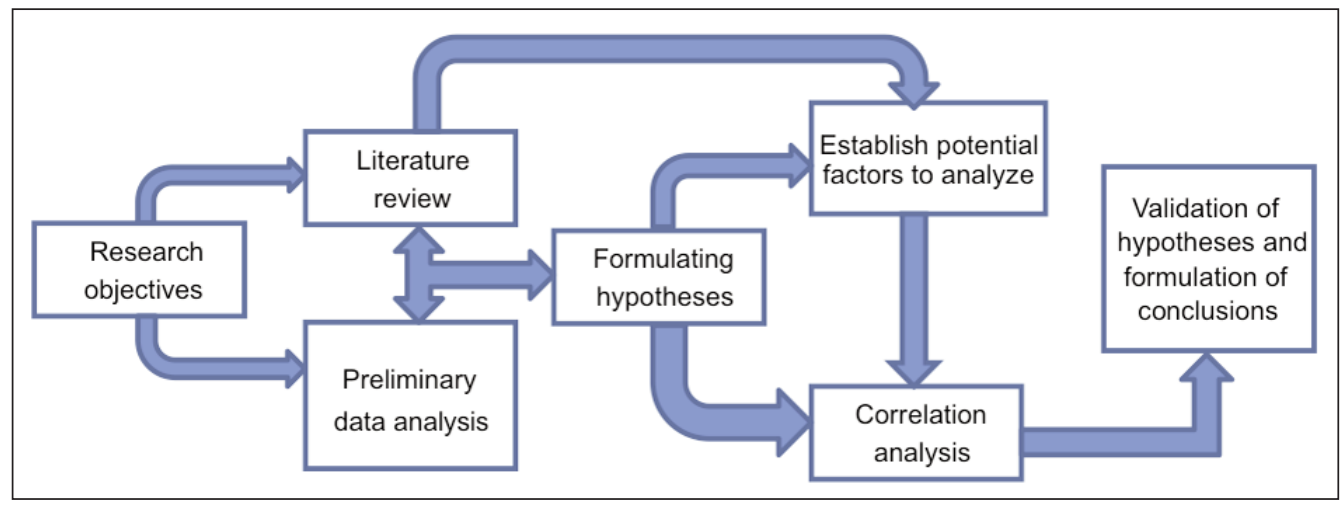

Fig. 1. Research methodology

1. The establishment of the research objectives was done taking into account the results obtained in other studies, the actual context of the research and the scientific importance of the analysis of the influence factors on the innovative projects.

2. Literature review focused on a technical-economic approach both studies concerning the analysis of the effects of innovative projects on the textile industry and on the main determinants of the scale of this type of projects in the textile industry.

3. Preliminary data analysis was conducted to identify the most relevant data sources available. Eurostat databases and national databases were selected:

- "Sold production, exports and imports by PRODCOM list (NACE Rev. 2) - annual data" (DS-066341), for NACE codes 13-15, "manufacture of textiles, wearing apparel, leather and related products".

- "Total production by PRODCOM list (NACE Rev. 2) - annual data" (DS-066342), Volume index of production for NACE codes 13-15, "manufacture
5. The identification of the potential factors to be analyzed was based on the study of literature and previous research. A number of 12 potential factors to be analyzed were identified.

6. The analysis of the correlations between the potential factors and the innovative product, management and marketing projects made in the textiles, wearing apparel, leather and related products industry in Romania was made on the basis of the chronological series from the above-mentioned databases. Correlation analysis was performed using the Pearson correlation coefficient $(r)$.

7. The validation of the hypotheses and the formulation of the conclusions was based on the previous steps and especially on the results obtained in the analysis of the correlations between the potential influence factors and the innovative product, management and marketing projects in Romania.

\section{RESEARCH HYPOTHESES}

Based on literature review and the results obtained in other studies conducted on the same topic, seven 
hypotheses for the research were formulated. The hypotheses were formulated based on the consideration of 12 potential influence factors: volume index of production in EU for NACE codes 13-15; volume index of production in Romania for NACE codes 1315; index of turnover (EU) for NACE codes 13-15; index of turnover (Romania) for NACE codes 13-15; employed HRST in EU; employed HRST in Romania; persons with tertiary education (ISCED) and/or employed in science and technology in EU; persons with tertiary education (ISCED) and/or employed in science and technology in Romania; total expenditure on R\&D activity of enterprises in the textiles manufacturing sector; net investment in textile manufacturing; enterprises using software solutions.

$\mathrm{H}$.1. There is a strong positive correlation between the volume index of production in the European Union and the number of innovative projects in the textiles, wearing apparel, leather and related products industry.

H.1.a. There is a strong positive correlation between the volume index of production in the European Union and the number of innovative product/process projects in the textiles, wearing apparel, leather and related products industry.

H.1.b. There is a strong positive correlation between the volume index of production in the European Union and the number of innovative management projects in the textiles, wearing apparel, leather and related products industry.

H.1.c. There is a strong positive correlation between EU index volumes of production and the number of innovative marketing projects in the textiles, wearing apparel, leather and related products industry.

$\mathrm{H}$.2. There is a strong positive correlation between the index turnover in the European Union and the number of innovative projects in the textiles, wearing apparel, leather and related products industry.

H.3. There is a strong positive correlation between the value of Romanian exports and the number of innovative projects in the textiles, wearing apparel, leather and related products industry.

H.3.a. There is a strong positive correlation between the volume of Romanian exports and the number of innovative products projects in the textiles, wearing apparel, leather and related products industry.

H.3.b. There is a strong positive correlation between the volume of Romanian exports and the number of innovative management projects in the textiles, wearing apparel, leather and related products industry.

H.3.c. There is a strong positive correlation between the volume of Romanian exports and the number of innovative marketing projects achieved.

H.4. There is a strong link between Employed HRST (Human Resource in Science and Technology) and innovative projects in the textiles, wearing apparel, leather and related products industry.

H.4.a. There is a strong link between Employed HRST (Human Resource in Science and Technology) in the European Union and innovative projects in the textiles, wearing apparel, leather and related products industry.

H.4.b. There is a strong link between employed HRST (Human Resource in Science and Technology) in Romania and innovative projects in the textiles, wearing apparel, leather and related products industry.

H.5. There is a strong positive correlation between people with tertiary education (ISCED) and/or employed in science and technology and innovative process or product projects.

H.6. There is a strong link between the total expenditure in the $R \& D$ activity of enterprises in the textiles manufacturing sector and the number of innovative projects in the textiles, wearing apparel, leather and related products industry.

H.7. There is a strong correlation between the net investment in the textile industry and the number of innovative projects.

H.8. There is a strong positive correlation between the number of enterprises using software solutions and the number of innovative projects in the textiles, wearing apparel, leather and related products industry.

\section{RESEARCH RESULTS}

The results of the correlation analysis between 11 factors of influence and the number of innovative product/process projects, innovative marketing and management projects, are presented in the table 1.

The first hypothesis of research, the existence of a positive and strong correlation between the volume index of production in EU for NACE codes 13-15 and the number of innovative projects is confirmed both for innovative product designs $(r=0.979)$ and for innovative marketing and management $(r=0.999)$. There is no equally strong link between NACE codes 13-15 and the number of innovative projects in the manufacture of textiles, wearing apparel, leather and related products.

The second hypothesis of research is not confirmed as the correlations between NACE codes 13-15 and the number of innovative products (product, process, marketing and management) is statistically significant, showing a strong link between the variables analyzed but is not positive. The level of turnover either at national or local level does not significantly influence the number of innovative projects in the textiles, wearing apparel, leather and related products industry.

The third hypothesis of research confirming the positive and strong correlation between NACE codes 13-15 and innovative projects is confirmed as the correlation is strong and positive for all types of innovative projects considered $(r=1.00)$. Romanian exports of textiles, wearing apparel, leather and related products are the most significant determinant of the number of innovative projects in this field.

The fourth hypothesis is only partially confirmed as there is a strong but negative correlation between 


\begin{tabular}{|c|c|c|c|c|}
\hline No. & $\begin{array}{l}\text { Influence factors / Innovative } \\
\text { projects }\end{array}$ & $\begin{array}{l}\text { Product and process } \\
\text { innovative projects }\end{array}$ & $\begin{array}{c}\text { Marketing } \\
\text { innovative projects }\end{array}$ & $\begin{array}{l}\text { Management } \\
\text { innovative projects }\end{array}$ \\
\hline 1 & $\begin{array}{l}\text { Volume index of production in EU for } \\
\text { NACE codes } 13-15\end{array}$ & 0.979 & 0.999 & 0.999 \\
\hline 2 & $\begin{array}{l}\text { Volume index of production in Romania } \\
\text { for NACE codes } 13-15\end{array}$ & -0.488 & -0.644 & -0.875 \\
\hline 3 & $\begin{array}{l}\text { Index of turnover (EU) for NACE codes } \\
13-15\end{array}$ & -0.674 & -0.802 & -0.832 \\
\hline 4 & $\begin{array}{l}\text { Index of turnover (Romania) for NACE } \\
\text { codes } 13-15\end{array}$ & -0.733 & -0.849 & -0.875 \\
\hline 5 & Exports value for NACE codes $13-15$ & 1.000 & 1.000 & 1.000 \\
\hline 6 & Employed HRST in EU & -0.916 & -0.976 & -0.986 \\
\hline 7 & Employed HRST in Romania & 0.192 & 0.374 & 0.422 \\
\hline 8 & $\begin{array}{l}\text { Persons with tertiary education (ISCED) } \\
\text { and/or employed in science and } \\
\text { technology in EU }\end{array}$ & -0.898 & -0.965 & -0.977 \\
\hline 9 & $\begin{array}{l}\text { Persons with tertiary education (ISCED) } \\
\text { and/or employed in science and } \\
\text { technology in Romania }\end{array}$ & -0.782 & -0.650 & -0.609 \\
\hline 10 & $\begin{array}{l}\text { Total expenditure on R \& D activity of } \\
\text { enterprises in the textiles manufacturing } \\
\text { sector }\end{array}$ & 0.008 & 0.197 & 0.248 \\
\hline 11 & Net investment in textile manufacturing & -0.397 & -0.564 & -0.606 \\
\hline 12 & Enterprises using software solutions & 0.756 & 0.501 & 0.455 \\
\hline
\end{tabular}

HRST (Human Resource in Science and Technology) employed in the European Union and innovative projects but there is not the same strength in the HRST (Human Resource in Science and Technology) at national level and the number of innovative projects in the field. The fifth hypothesis is not confirmed because there is no correlation between persons with tertiary education (ISCED) and/or employed in science and technology in EU or in Romania and the number of innovative projects in the field.

Also, the sixth and seventh hypotheses are not confirmed because there are no significant correlations between the number of innovative projects in the field and total expenditures from the R\&D activity of enterprises in the textiles manufacturing sector or net investment in textile manufacturing.

The eighth hypothesis, the link between enterprises using software solutions and the number of innovative projects, is only partially confirmed for innovative product/process projects $(r=0.756)$ and less for marketing innovative projects and management innovative projects. These two types of projects are dependent on the computerization of activities but not on the same level as product and process innovative projects. Table 2 contains a summary of the hypotheses that have marked the research and their confirmation.

\section{CONCLUSIONS}

In the literature there have been several studies on the content of innovative textile projects, the effects of innovative projects, the main determinants of innovative textile projects. The studies were focused either on a particular geographic region or on a particular type of organization (the most common studies conducted on SMEs). There were no other similar studies before the research that analyzed the main factors of influence on the number of innovative projects in the Romanian textiles, wearing apparel, leather and related products industry.

The analysis of the factors influencing the number of innovative projects in the industry was based on the identification of 11 potential factors of influence, preliminary data analysis, selection of significant data series from EUROSTAT databases and national databases and analysis of correlations between the main types of projects (product, process, marketing and management) and the eleven influence factors identified.

Of the seven hypotheses formulated, two (hypotheses 1 and 3) were fully confirmed, showing a strong and positive correlation between the number of innovative projects and:

- volume index of production in EU for NACE codes 13-15;

- exports value for NACE codes 13-15.

The value of Romanian exports and production in the European Union are the main determinants of innovation and the number of innovative projects in the field. A partially confirmed hypothesis is the fourth hypothesis, confirmed only for employed HRST 


\begin{tabular}{|c|c|c|}
\hline No. & Hypotheses & Result \\
\hline 1. & $\begin{array}{l}\text { H.1. There is a strong positive correlation between the volume index of production in } \\
\text { the European Union and the number of innovative projects in the textiles, wearing } \\
\text { apparel, leather and related products industry. }\end{array}$ & Confirmed \\
\hline 2. & $\begin{array}{l}\text { H.2. There is a strong positive correlation between the index turnover in the European } \\
\text { Union and the number of innovative projects in the textiles, wearing apparel, leather } \\
\text { and related products industry. }\end{array}$ & Not confirmed \\
\hline 3. & $\begin{array}{l}\text { H.3. There is a strong positive correlation between the value of Romanian exports and } \\
\text { the number of innovative projects in the textiles, wearing apparel, leather and related } \\
\text { products industry. }\end{array}$ & Confirmed \\
\hline 4. & $\begin{array}{l}\text { H.4. There is a strong link between Employed HRST (Human Resource in Science } \\
\text { and Technology) and innovative projects in the textiles, wearing apparel, leather and } \\
\text { related products industry. }\end{array}$ & Partially confirmed \\
\hline 5. & $\begin{array}{l}\text { H.5. There is a strong positive correlation between people with tertiary education } \\
\text { (ISCED) and/or employed in science and technology and innovative process or } \\
\text { product projects. }\end{array}$ & Not confirmed \\
\hline 6. & $\begin{array}{l}\text { H.6. There is a strong link between the total expenditure in the } R \& D \text { activity of } \\
\text { enterprises in the textiles manufacturing sector and the number of innovative projects } \\
\text { in the textiles, wearing apparel, leather and related products industry. }\end{array}$ & Not confirmed \\
\hline 7. & $\begin{array}{l}\text { H.7. There is a strong correlation between the net investment in the textile industry } \\
\text { and the number of innovative projects. }\end{array}$ & Not confirmed \\
\hline 8. & $\begin{array}{l}\text { H.8. There is a strong positive correlation between the number of enterprises using } \\
\text { software solutions and the number of innovative projects in the textiles, wearing } \\
\text { apparel, leather and related products industry. }\end{array}$ & Partially confirmed \\
\hline
\end{tabular}

(Human Resource in Science and Technology) in the European Union. Partially confirmed is the eighth hypothesis, showing a strong link between number of enterprises using software solutions and the number of innovative projects in the textiles, wearing apparel, leather and related products industry.

Of the eleven potential factors of influence, only three have a strong influence on the scale of innovative projects in the field (volume index of production in EU for NACE codes 13-15; exports value for NACE codes 13-15; employed HRST) and only two of them volume index of production in EU for NACE codes 13-15; exports value for NACE codes 13-15) have a positive influence.

The research, although very statistically significant, was focused on the economic factors that condition innovation. For this reason, it should be continued with a questionnaire survey that captures the qualitative factors that influence the innovative projects in the field.

\section{BIBLIOGRAPHY}

[1] Ceptureanu, S.I., Ceptureanu, E.G., Simion-Melinte, C., Borisov, D. Capabilities of SMEs in Romanian clothing industry, In: Industria textilă, vol. 67, nr. 4, 2016, pp. 265-269

[2] Ceptureanu, S.I., Ceptureanu, E.G., Visileanu, E., Comparative analysis of small and medium enterprises organizational performance in clothing industry, In: Industria textilă, vol. 68, Issue 2, 2017, pp. 156-162

[3] Gîrneaţă, A., Giurgiu, A., Dobrin, O.C., Popa, I., Popescu, D., Cuc, S., Voicu, L. Performance management practices in Romanian textile and clothing companies, In: Industria textilă, vol. 66, nr. 2, 2015, pp. 108-113

[4] Florescu, M.S., Ivanov, F. Globalization as a factor of influence on the R\&D activity and the case of the textile industry in Romania, In: Industria Textilă, vol. 67, nr. 5, 2016, pp. 345-350

[5] Jayatilake, H.S.B., Withanaarachchi, A.S. Industry 4.0 in the apparel-manufacturing sector: Opportunities for Sri Lanka, 1st Interdisciplinary Conference of Management Researchers, at Sabaragamuwa University of Sri Lanka, 2016

[6] Kaounides, L., Yu, H., Harper, T. Nanotechnology innovation and applications in textiles industry: Current markets and future growth trends, In: Materials Technology Advanced Performance Materials Volume 22, 2007, Issue 4, pp. 209-237

[7] Lottersberger, A., Design driven innovation for Textile Industry, In: Advanced Materials Research, vol. 331, 2011, pp. 730-734

[8] Macchion, L., Moretto, A., Caniato, F., Caridi, M., Danese, P., Spina, G., Vinelli A. Improving innovation performance through environmental practices in the fashion industry: the moderating effect of internationalization and the 
influence of collaboration, In: Production Planning \& Control.The Management of Operations, Volume 28, Issue 3, 2017, pp. 190-201

[9] Popescu, D.I. The correspondence between workforce skills and company needs, In: Industria Textilă, vol. 64, Isuue 3, 2013, pp. 168-175

[10] Şerbănel, C.I., Romanian textile industry and its competitive advantage, In: SEA - Practical Application of Science Volume II, Issue 2 (4) /2014, pp. 395-404

[11] Vogler-Ludwig, K., Valente, A.M. Skills scenarios for the textiles, wearing apparel and leather products sector, In: Final Report undertaken for the European Commission, Employment, Social Affairs and Equal Opportunities DG, Unit Working Conditions, Adaptation to Change, 2009

[12] Zucchella, A., Siano, A. Internationalization and innovation as resources for SME growth in foreign markets. In: A Focus on Textile and Clothing Firms in the Campania Region, International Studies of Management \& Organization, Volume 44, Issue 1, 2014, pp. 21-41

\section{Authors: \\ CEZAR-PETRE SIMION ${ }^{1}$ \\ ADRIANA ALEXANDRU² \\ SEBASTIAN ION CEPTUREANU 1 \\ EDUARD GABRIEL CEPTUREANU ${ }^{1}$}

${ }^{1}$ Bucharest University of Economic Studies, Faculty of Management, Bucharest, Romania

2 National Institute for Research and Development in Informatics, Bucharest, Romania e-mail: cezar.simion@man.ase.ro; adriana_alexandru@yahoo.com; sebastian.ceptureanu@man.ase.ro; eduard.ceptureanu@man.ase.ro

Corresponding author:

CEZAR-PETRE SIMION

e-mail: cezar.simion@man.ase.ro



